Notes

\title{
RECONSIDERING THE SHAM AFFIDAVIT DOCTRINE
}

\author{
COllin J. COX
}

\section{INTRODUCTION}

After the Second World War, Michael Dercacz, a Ukrainian, applied for U.S. citizenship. In response to a question on the naturalization application, Dercacz stated he had never committed a crime of "moral turpitude," an act which would have barred him from obtaining citizenship. Since Dercacz appeared to meet all the statutory requirements, his petition for naturalization was granted on November 11, $1954 .^{1}$

Yet while completing the application-and for almost thirty subsequent years-Dercacz concealed from authorities that in 1941 he had voluntarily joined a Ukrainian police unit. This unit, which eventually submitted to Nazi German control, persecuted and murdered 2,000 Jewish Ukrainian citizens. ${ }^{2}$ After discovering this information in 1982, the federal government brought a civil action in federal district court under section 340(a) of the Immigration and Nationality Act of $1952^{3}$ to set aside Dercacz's grant of naturalization. In its complaint, the government alleged that Dercacz was ineligible for naturalization because he had violated U.S. immigration law by "assist[ing] the enemy in persecuting civil populations."4

During a deposition, Dercacz admitted to having served as a "uniformed, armed member of the Ukrainian police... during the time of the virtual incarceration and subsequent extermination of the

\footnotetext{
Copyright (C) 2000 by Collin J. Cox.

1. See United States v. Dercacz, 530 F. Supp. 1348, 1349-50 (E.D.N.Y. 1982).

2. See id.

3. 8 U.S.C. $\S 1451$ (a) (1994).

4. Dercacz, 530 F. Supp. at 1350.
} 
2,000 Jews." " He further acknowledged that his duties included capturing Jews who refused to wear identifying armbands and releasing to the Gestapo the names of Ukrainians who had aided incarcerated Jews. ${ }^{6}$ On these admissions, the government moved for summary judgment. ${ }^{7}$

Dercacz then submitted an affidavit in which he denied having had "any contact or anything to do with the Jewish Ghetto or persons generally in the ... Police District," a statement that contradicted his deposition testimony. ${ }^{8}$ Despite his argument that the affidavit created a genuine issue of fact warranting jury resolution, the federal district court disregarded it as a "sham." The court concluded that Dercacz's prior deposition admissions left no doubt that he had "assisted the Nazis in persecuting civilian Jews." "Holding that no genuine issue of material fact existed, the federal district judge granted summary judgment to the government, revoking Dercacz's citizenship. ${ }^{10}$

While the factual scenario of Dercacz is unique, the procedural issue raised by the case is not. Federal and state courts have encountered numerous comparable situations, in which litigants responding to summary judgment motions have contradicted prior deposition testimony in subsequent affidavits. ${ }^{11}$ The rules of civil procedure in the federal and state systems do not specify how courts should treat such affidavits. Nevertheless, as in Dercacz, federal and state judges have often disregarded "offsetting affidavits," citing the "sham affidavit doctrine" for authority. This doctrine derives originally from the Second Circuit's 1969 decision, Perma Research \& Development Co. v. Singer Co ${ }^{13}$ Subsequent courts ruling on summary judgment motions have often relied on Perma Research to disregard offsetting affidavits. ${ }^{14}$

5. $I d$.

6. See id. at 1351.

7. See id.

8. Id. at 1350

9. Id. at 1351 .

10. See id. at 1353 .

11. See infra Part I.B-C.

12. For the purposes of this Note, I will refer to affidavits that are submitted in response to motions for summary judgment and contradict prior deposition testimony as "offsetting affidavits." Although this term has its shortcomings, the alternative, "contradictory affidavits," incorrectly implies the existence of two independent affidavits.

13. 410 F.2d 572 (2d Cir. 1969).

14. See infra notes $38-47$ and accompanying text. 
Yet some situations involving offsetting affidavits remain highly questionable. In cases such as Dercacz, where the contradiction is both unqualified and unexplained, an offsetting affidavit can, indeed, appear a mere sham. ${ }^{15}$ Not every court has applied the doctrine in a mechanical manner, however, either because the alleged contradiction is less clear or because the court believes the affiant's explanation for the contradiction. In recent years, splits of authority regarding the sham affidavit doctrine have emerged, both between federal courts of appeals and between state courts. For example, while the Second Circuit presumes that an offsetting affidavit contradicting previous deposition testimony is a sham, ${ }^{16}$ the Fifth Circuit generally considers the contexts in which offsetting affidavits are submitted. ${ }^{17}$

The United States Supreme Court has not directly addressed the propriety of the sham affidavit doctrine. Nevertheless, some lower federal courts have argued that the doctrine is justified as a manifestation of the trial judge's inherent powers. ${ }^{18}$ Other lower federal courts, however, have argued that when applied to certain offsetting affidavits, the doctrine encroaches on the jury's factfinding domain. ${ }^{19}$ These arguments have carried more weight in some state courts, where reaction to the sham affidavit doctrine has differed

15. See United States v. Dercacz, 530 F. Supp. 1348, 1350-51 (E.D.N.Y. 1982); see also Jones v. General Motors Corp., 939 F.2d 380, 384-85 (6th Cir. 1991) (ignoring an offsetting affidavit when the plaintiff had denied the assertion made in the affidavit ten times during a previous deposition); Schuyler v. United States, 987 F. Supp. 835, 839-41 (S.D. Cal. 1997) (discrediting an affiant's attempt to "back pedal" his own deposition representations regarding the site of his injury); Selsor v. Callaghan \& Co., 609 F. Supp. 1003, 1010 (N.D. Ill. 1985) (rejecting an offsetting affidavit on the basis that the conflict with prior deposition testimony was patently incredible).

16. See, e.g., Margo v. Weiss, 213 F.3d 55, 60-61 (2d Cir. 2000) (refusing to allow the plaintiffs to "defeat a motion for summary judgment by responding with affidavits recanting that earlier testimony"); Hayes v. New York City Dep't of Corrections, 84 F.3d 614, 619 (2d Cir. 1996) (holding that "factual issues created solely by an affidavit crafted to oppose a summary judgment motion are not 'genuine' issues for trial"); Mack v. United States, 814 F.2d 120, 124 (2d Cir. 1987) ("It is well settled in this circuit that a party's affidavit which contradicts his own prior testimony should be disregarded on a motion for summary judgment."). But see Thomas v. Roach, 165 F.3d 137, 144 (2d Cir. 1999) (allowing an affiant who had made "vague and inconclusive" statements regarding a knife to clarify those statements in a subsequent deposition).

17. See, e.g., Kennett-Murray v. Bone, 622 F.2d 887, 893-94 (5th Cir. 1980) (holding that an affidavit created a genuine issue of fact because it merely explained an alleged inconsistency already existing in a deposition).

18. See infra notes 38-51 and accompanying text.

19. See infra notes 52-57 and accompanying text. 
somewhat. State trial judges have appeared generally more receptive to litigants' explanations for contradictions, with some even rejecting the Perma Research doctrine outright.

The scholarly literature is replete with sophisticated critiques of summary judgment procedure,$^{20}$ but there are few studies of the sham affidavit doctrine, and no source compiles reactions to the doctrine in state courts. Some authors have, however, identified the recent divisions among certain federal circuits. $^{21}$ One has noted the continuing relevance of the sham affidavit doctrine in most jurisdictions. ${ }^{22}$ Another article has acknowledged that the doctrine has been used with increasing frequency in recent years. ${ }^{23}$ Some commentators have even criticized the doctrinal foundations of the sham affidavit doctrine, arguing that it can violate the central tenet that judges should not determine issues of fact. ${ }^{24}$

20. See, e.g., Jonathan T. Molot, How Changes in the Legal Profession Reflect Changes in Civil Procedure, 84 VA. L. REV. 955, 988 (1998) ("Unfortunately, the Federal Rules' central issue-narrowing mechanism-summary judgment under Rule 56-has proved to be inadequate. In most civil suits summary judgment is unavailable to narrow disputed issues. Legal standards have evolved to make summary judgment more difficult than the drafters may have envisioned ...."). Judge Patricia M. Wald of the District of Columbia Circuit has commented:

I believe our circuit's experience shows that we are now at a stage where the focus should be on ensuring that summary judgment stays within its proper boundaries, rather than on encouraging its unimpeded growth. Its expansion across subject matter boundaries and its frequent conversion from a careful calculus of factual disputes (or the lack thereof) to something more like a gestalt verdict based on an early snapshot of the case have turned it into a potential juggernaut which, if not carefully monitored, could threaten the relatively small residue of civil trials that remain.

Patricia M. Wald, Summary Judgment at Sixty, 76 TEX. L. REV. 1897, 1917 (1998).

21. See, e.g., Edward Brunet, Summary Judgment Materials, 147 F.R.D. 647, 664-69 (1993) (recognizing the split between circuits that apply the sham affidavit doctrine and those that do not); Jeffrey L. Freeman, Annotation, Propriety, Under Rule 56 of the Federal Rules of Civil Procedure, of Granting Summary Judgment When Deponent Contradicts in Affidavit Earlier Admission of Fact in Deposition, 131 A.L.R. FED. 403, 413-19 (1996) (itemizing the circuits and particular cases in which the sham affidavit doctrine was or was not applied).

22. See Darrell S. Gay, The Importance of Summary Judgment in Defending Civil Rights Cases, in Litigating EMPloyment Discrimination CASES 65, 96 (PLI Litigation Course Handbook Series, 1996):

In light of the anti-sham rule, it is important for defense counsel to uncover any and all prior sworn testimony or statements made by either a party or a witness who will testify at a deposition.... [D]eposition testimony must be consistent with any statements made in a later affidavit in support of a motion for summary judgment. If later sworn testimony conflicts with earlier testimony on a material issue of fact, the court will consider the later testimony a "sham," unless it falls within one of the exceptions to the rule.

23. See Randall R. Riggs \& Nelson D. Alexander, Dilemma of Conflicting Sworn Testimony in Summary Judgment, 61 DEF. Couns. J. 461, 469 (1994).

24. See, e.g., James Joseph Duane, The Four Greatest Myths About Summary Judgment, 52 WASH. \& LEE L. REV. 1523, 1595-1611 (1995) (arguing that a judge can handle offsetting 
Though some form of the sham affidavit doctrine has been endorsed in every federal court of appeals that has considered it, its justifications have received scant attention in legal journals. This Note attempts to fill that void, arguing that, while rigidly applying the doctrine to disregard all offsetting affidavits is unjustifiable, the fundamental principle of the doctrine is consistent with the court's responsibility to allow only genuine issues of material fact to progress to trial. The Note further contends that trial judges can-and should-engage in affidavit-specific determinations to decide whether an outstanding genuine issue requires jury resolution. In reaching this conclusion, courts should accord respondents to summary judgment motions all reasonable inferences. Yet this Note concludes that when an offsetting affidavit flatly contradicts prior deposition testimony without explanation, as in Dercacz, an inference of its credibility is not reasonable, its disregard is warranted, and summary judgment is justified.

Part I of this Note broadly traces the history of the sham affidavit doctrine, considering Federal Rule of Civil Procedure 56, the leading federal cases in the area, and the divergent approaches to offsetting affidavits adopted by state courts. Part II presents the basic justification for the doctrine-that sham affidavits do not create genuine issues of fact. Instead, sham affidavits represent spurious attempts to survive motions for summary judgment. Part III then considers two issues central to defining the proper scope of the doctrine-the necessity of allowing certain excuses for contradiction and the application of the rule to statements by nonparties. Part IV offers two possible reforms that would clarify the sham affidavit doctrine; ultimately, however, the Note offers a qualified endorsement of the present approach to offsetting affidavits in most federal and state jurisdictions.

\section{THE History OF THE SHAM AfFIDAVIT DoctRINE}

\section{A. Rule 56}

The chief reason for the indecision among federal courts regarding some aspects of the sham affidavit doctrine is that the

affidavits without usurping the function of the jury); Michael Holley, Making Credibility Determinations at Summary Judgment: How Judges Broaden Their Discretion While "Playing by the Rules," 20 WHITTIER L. REV. 865, 887-904 (1999) (contending that the sham affidavit doctrine allows judges to make credibility determinations and exercise "forbidden discretion"). 
Federal Rules of Civil Procedure do not address situations involving offsetting affidavits. Rule 56, which governs summary judgment in the federal judicial system, allows courts to grant such motions only in limited circumstances:

The [summary] judgment sought shall be rendered forthwith if the pleadings, depositions, answers to interrogatories, and admissions on file, together with the affidavits, if any, show that there is no genuine issue as to any material fact and that the moving party is entitled to a judgment as a matter of law. ${ }^{25}$

The plain language of this rule allows affidavits to be considered in summary judgment motions, and affidavits are central to summary judgment practice. ${ }^{26}$ Indeed, Rule 56(e) permits parties to oppose summary judgment motions with affidavits that "set forth specific facts showing that there is a genuine issue for trial." ${ }^{27}$ The original version of Rule 56 empowered the court to require any affiant to be present for examination or cross-examination, ${ }^{28}$ providing the trial judge an opportunity to question the affiant about any contradictions with prior testimony. Yet the only textual check on fraudulent affidavits in the current version of the Federal Rules of Civil Procedure is Rule 56(g), which only shifts certain costs associated with responding to such affidavits:

Should it appear to the satisfaction of the court at any time that any of the affidavits presented pursuant to this rule are presented in bad faith or solely for the purpose of delay, the court shall forthwith order the party employing them to pay to the other party the amount of the reasonable expenses which the filing of the affidavits caused the other party to incur, including reasonable attorney's fees, and any offending party or attorney may be adjudged guilty of contempt. $^{29}$

While such sanctions can be severe, the rule does not prescribe that district courts prohibit certain offsetting affidavits, leaving a large gap in the Federal Rules. Nevertheless, trial judges have sometimes mistaken the long line of cases precluding the consideration of sham

\footnotetext{
25. FED. R. CIV. P. 56(c).

26. See 11 James WM. Moore et AL., Moore’s Federal Practice $§ 56.14[1][\mathrm{a}]$ (3d ed. 2000).

27. FED. R. CIV. P. 56(e).

28. See Richard L. Marcus, Completing Equity's Conquest? Reflections on the Future of Trial Under the Federal Rules of Civil Procedure, 50 U. PITT. L. REV. 725, 740 (1989).

29. FED. R. CIV. P. 56(g).
} 
affidavits for a prohibition found in Rule 56. A federal judge in Kansas, for example, stated: "Under the Federal Rules of Civil Procedure, a party opposing a motion for summary judgment may not attempt to create a sham fact issue to defeat the motion through the submission of affidavits which conflict with earlier sworn statements." ${ }^{30}$ Yet the Federal Rules of Civil Procedure do not contain an express prohibition of offsetting affidavits; the sham affidavit doctrine has derived instead from the courts.

\section{B. Leading Federal Cases}

Much of the lore surrounding the sham affidavit doctrine originated with the Second Circuit's decision in Perma Research \& Development Co. v. Singer Co. ${ }^{31}$ Perma Research developed an automobile anti-skid braking device and licensed the patent rights to Singer. After approximately eight months, Singer concluded that the braking device was hopelessly defective and commenced a product recall. Perma Research then sued for breach of contract, claiming that Singer had committed fraud by signing a contract it never intended to perform. ${ }^{32}$

Perma Research's president, Frank A. Perrino, the key witness in the litigation, endured four days of depositions, during which he could not remember a single instance when Singer employees had acted in a fraudulent manner. ${ }^{33}$ Based on this admission, Singer moved for summary judgment. ${ }^{34}$ Perrino then filed an affidavit stating that a Singer employee once told him Singer "never had any intention" of performing the contract. ${ }^{35}$ This affidavit, Perma Research argued, presented a triable issue of material fact, rendering summary judgment inappropriate. The trial judge disagreed, disregarding the offsetting affidavit and granting summary judgment to Singer. ${ }^{36}$

On appeal, the Second Circuit affirmed, holding that Perma Research had failed to raise a genuine issue:

30. Maddy v. Vulcan Materials Co., 737 F. Supp. 1528, 1532 (D. Kan. 1990) (disregarding the plaintiff's affidavit as a sham, since his contrary previous deposition testimony was "clear and unequivocal," with "no indication of confusion or ambiguity").

31. 410 F.2d 572 (2d Cir. 1969).

32. See id. at 573-74.

33. See id. at $577-78$

34. See id. at 574 .

35. Id. at 577 .

36. See id. at 576. 
If there is any dispute as to the material facts, it is only because of inconsistent statements made by Perrino the deponent and Perrino the affiant.... If a party who has been examined at length on deposition could raise an issue of fact simply by submitting an affidavit contradicting his own prior testimony, this would greatly diminish the utility of summary judgment as a procedure for screening out sham issues of fact. ${ }^{37}$

The last four words of this excerpt have had a lasting impact. Since 1969, several federal courts of appeals have endorsed the Perma Research holding and its prohibition against "sham" affidavits. For instance, in Radobenko v. Automated Equipment Corp. ${ }^{38}$ the Ninth Circuit upheld a grant of summary judgment against the plaintiff, who had submitted an offsetting affidavit, concluding:

The very object of summary judgment is to separate real and genuine issues from those that are formal or pretended, so that only the former may subject the moving party to the burden of trial. Here we are convinced that the issues of fact created by [the plaintiff] are not issues which this Court could reasonably characterize as genuine; rather, they are sham issues which should not subject the defendants to the burden of a trial. ${ }^{39}$

Other federal courts have applied the Perma Research doctrine to hold that when an offsetting affidavit contradicts prior deposition testimony, the affidavit should be completely disregarded. ${ }^{40}$ These courts, often declaring that a litigant herself cannot create a material issue of fact with her previous statements, have sometimes appeared so predisposed against offsetting affidavits that they have ignored potentially mitigating factors. Many of these federal courts submit that if litigants could, without penalty, offer affidavits that contradict previous testimony, summary judgment would be eviscerated. Chief Judge Richard Posner of the Seventh Circuit has concluded, for

37. Id. at 578 .

38. 520 F.2d 540 (9th Cir. 1975).

39. Id. at 544 (citations omitted).

40. See, e.g., Adams v. Greenwood, 10 F.3d 568, 572 (8th Cir. 1993) ("[A]n affidavit denying what is established by one's own evidence ... does not preclude summary judgment."); Jones v. General Motors Corp., 939 F.2d 380, 385 (6th Cir. 1991) (denying summary judgment when an affidavit contradicted prior deposition testimony); Hartley v. Wisconsin Bell, Inc., 930 F. Supp. 349, 354 (E.D. Wis. 1996) (disregarding an affidavit that did not present "additional factual propositions"); $c f$. Margo v. Weiss, 213 F.3d 55, 60-61 (2d Cir. 2000) (applying the Perma Research principle to prohibit the filing of delayed errata sheets and supplemental answers to interrogatories in an attempt to avoid summary judgment). 
example: "The concern in litigation ... is that a party will first admit no knowledge of a fact but will later come up with a specific recollection that would override the earlier admission." ${ }^{41}$

In one Illinois federal district court proceeding, the plaintiff answered a deposition question in a manner that cast doubt on her claim under the Americans with Disabilities Act (ADA). The plaintiff, who suffered from chronic psoriasis, admitted to defense counsel that because she could still "function in everyday-life activities," her condition had not physically "affected" her in that sense. ${ }^{42}$ During redirect examination, however, the plaintiff recanted her previous statement and claimed that her psoriasis physically "affected" her in another way-namely, by "distort[ing] [her] appearance." ${ }^{43}$ When the defendant moved for summary judgment based on the plaintiff's first admission, the plaintiff submitted an affidavit that again described the physical effects of her psoriasis. ${ }^{44}$ Although the court acknowledged that the revised answer "could arguably support the notion that [the plaintiff] is disabled for ADA purposes," summary judgment for the defendant, ${ }^{46}$ refusing to accord the plaintiff the reasonable inference that acute psoriasis in fact changes one's appearance.

Although several federal courts have reached similar results, holding that offsetting affidavits may never be considered in summary judgment motions, ${ }^{47}$ the Perma Research court actually held that trial judges must engage in two separate inquiries, first determining if a contradiction exists and then determining whether the contradiction is justified. Specifically, the court concluded that trial judges cannot

41. Buckner v. Sam's Club, Inc., 75 F.3d 290, 292-93 (7th Cir. 1996) (refusing to allow the plaintiff's offsetting affidavit to preclude summary judgment, when the plaintiff had stated during her deposition that she "did not know" what object in the defendant's store had caused her fall, then asserted in an offsetting affidavit that the object was a ladies' watch, "one of the few objects that could directly link [the defendant] with the accident").

42. Gray v. Ameritech Corp., 937 F. Supp. 762,768 (N.D. Ill. 1996).

43. Id.

44. See id. at 768-69.

45. Id. at 769 .

46. The trial judge stated his refusal to "play ostrich ... bur[ying] [his head] ... in the sand" by ignoring that the plaintiff "received some "education" between the time of her deposition and the time she submitted the offsetting affidavit. $I d$. at 769.

47. See, e.g., Jones v. General Motors Corp., 939 F.2d 380, 385 (6th Cir. 1991) ("[I]t is well settled that a plaintiff may not create a factual issue for the purpose of defeating a motion for summary judgment by filing an affidavit contradicting a statement the plaintiff made in a prior deposition."). 
"exclude the [offsetting] affidavit[s] from consideration in the determination of the question whether there is any genuine issue as to any material fact" 48 and acknowledged that "there may be some instances where summary judgment is too blunt a procedural device." ${ }^{49}$ The Perma Research court found, however, that Mr. Perrino's depositions were so unambiguous that his offsetting affidavit, which directly contradicted his previous testimony, did not create a genuine issue of material fact. ${ }^{50}$

In more ambiguous situations, however, subsequent federal courts have found it difficult to differentiate offsetting affidavits creating genuine issues of material fact from those raising only sham issues. While the Second Circuit has remained hostile to offsetting affidavits, ${ }^{51}$ other circuits have endorsed more flexible approaches. The Ninth Circuit has reminded its district judges that they must first determine that an offsetting affidavit is a sham before declaring that no genuine issue of fact exists. ${ }^{52}$ Similarly, the Fifth Circuit has described summary judgment as a "lethal weapon," imploring courts to be "mindful of its aims and targets" and to avoid "overkill in its use." $" 53$

Additionally, another long line of federal cases undercuts the Perma Research rationale by holding that district courts cannot resolve factual disputes by weighing conflicting evidence, ${ }^{54}$ because they are "not authorized to resolve issues of fact on a motion for summary judgment." 55 The Fifth Circuit, for example, has declared that "[c]redibility assessments are not fit grist for the summary

48. Perma Research \& Dev. Co. v. Singer Co., 410 F.2d 572, 578 (2d Cir. 1969).

49. Id.

50. See id.

51. See supra note 16 and accompanying text.

52. See Kennedy v. Allied Mut. Ins. Co., 952 F.2d 262, 266-67 (9th Cir. 1991).

53. Brunswick Corp. v. Vineberg, 370 F.2d 605, 612 (5th Cir. 1967); see also Whitaker v. Coleman, 115 F.2d 305, 307 (5th Cir. 1940):

Summary judgment procedure is not a catch penny contrivance to take unwary litigants into its toils and deprive them of a trial, it is a liberal measure, liberally designed for arriving at the truth. Its purpose is not to cut litigants off from their right of trial by jury if they really have evidence which they will offer on a trial, it is to carefully test this out, in advance of trial by inquiring and determining whether such evidence exists. Rule 56 is carefully drawn to effectuate this purpose.

54. See, e.g., Farbwerke Hoeschst A. G. v. M/V "Don Nicky," 589 F.2d 795, 798 (5th Cir. 1979) ("[T] he court may not weigh conflicting affidavits to resolve disputed fact issues."); FritoLay, Inc. v. Morton Foods, Inc., 316 F.2d 298, 301 (10th Cir. 1963) (holding that a comparison of conflicting testimony "cannot conclusively negative the likelihood of confusion as a matter of law").

55. Choudhry v. Jenkins, 559 F.2d 1085, 1089 (7th Cir. 1977). 
judgment mill." ${ }^{56}$ Several of these federal courts have concluded that only juries may assess the comparative value of disputed evidence or choose between conflicting versions of the same events. ${ }^{57}$

Yet all federal courts that have considered the problems posed by offsetting affidavits have reconciled these seemingly conflicting holdings and concluded that the sham affidavit doctrine is justified. One reason cited for this conclusion is that previous depositions are more reliable than offsetting affidavits, which carry virtually no evidentiary weight. The Perma Research court declared that deposition testimony was more reliable "since the deponent was either cross-examined by opposing counsel, or at least available to opposing counsel for cross-examination." ${ }^{58}$ Several courts in different circuits have adopted this analysis ${ }^{59}$ with one court holding that the "adversarial" nature of depositions renders them more credible than affidavits. ${ }^{60}$ Moreover, the fact that affidavits are often drafted by attorneys (who presumably are aware of Rule 56's guidelines) undercuts their trustworthiness in certain circumstances. The Seventh Circuit explained:

We have been highly critical of efforts to patch up a party's deposition with his own subsequent affidavit. Almost all affidavits

56. Dibidale of La., Inc. v. American Bank \& Trust Co., 916 F.2d 300, $307-08$ (5th Cir. 1990).

57. See, e.g., Gross v. Southern Ry. Co., 414 F.2d 292, 297 (5th Cir. 1969) ("It is also well settled that in considering a motion for summary judgment, the court has no duty or function to try or decide factual issues. Its only duty is to determine whether or not there is an issue of fact to be tried."); Olin v. Disneyland Int'l, 832 F. Supp. 1342, 1344 (D. Ariz. 1993) (“[S]ummary judgment is not appropriate where the trial judge would be required to choose among competing or conflicting inferences or to pass on the credibility of witnesses with differing versions of material facts."). For further discussion, see Molot, supra note 20, at 992 ("[T]he Seventh Amendment is designed to preserve a system under which material issues of fact are for juries-not lawyers or judges-to decide.").

58. Perma Research \& Dev. Co. v. Singer Co., 410 F.2d 572, 578 (2d Cir. 1969).

59. See, e.g., Russell v. Acme-Evans Co., 51 F.3d 64, 67-68 (7th Cir. 1995) ("Where deposition and affidavit are in conflict, the affidavit is to be disregarded unless it is demonstrable that ... the deposition was mistaken ...."); Zorn v. Helene Curtis, Inc., 903 F. Supp. 1226, 1234 n.6 (N.D. Ill. 1995) (following the precedent set by the Seventh Circuit); Shearer v. Homestake Mining Co., 557 F. Supp. 549, 558 n.5 (D.S.D. 1983) ("[G]reater reliability is usually attributed to the deposition.").

60. See Darnell v. Target Stores, 16 F.3d 174, 176 (7th Cir. 1994) ("Inherently depositions carry an increased level of reliability. Depositions are adversarial in nature and provide the opportunity for direct and cross-examination."). Richard Marcus has contended that the sham affidavit doctrine is a manifestation of equitable concepts, involving "some intrinsic, and justifiable, weighing of the evidence to favor the deposition as compared to the affidavit." Marcus, supra note 28, at 771-72. 
submitted in litigation are drafted by the lawyers rather than by the affiants, and a comparison of the diction of [the plaintiff's] deposition with that of the affidavit makes clear that [this] affidavit is no exception. ${ }^{61}$

Perma Research, which compiled many of these objections to offsetting affidavits, is generally accepted as the leading federal case concerning such affidavits. While its holding gives rise to several concerns over the implementation of the sham affidavit doctrine, its impact on the subsequent treatment of offsetting affidavits in federal courts cannot be overstated.

\section{Leading State Cases}

More than their federal counterparts, state courts have struggled to determine the best method of handling offsetting affidavits that contradict prior deposition testimony. Since each state has its own rules of civil procedure, the differences between states are more pronounced than between federal courts of appeals. While some states endorse the sham affidavit doctrine, others reject it outright. Therefore, litigants submitting offsetting affidavits in state courts often encounter less trouble in raising genuine issues of fact.

Several states with summary judgment rules similar to Federal Rule 56 disregard sham affidavits as fraudulent representations. ${ }^{62}$ For example, one Ohio appellate court held: "[T] allow a party to avoid summary judgment by the simple filing of an affidavit contradicting,

61. Russell, 51 F.3d at 67 (citations omitted). Other courts, however, have rejected this proposition, reasoning that the particular facts and circumstances of the affidavit must be considered to determine its veracity. See, e.g., Dudo v. Schaffer, 91 F.R.D. 128, 131-33 (E.D. Pa. 1981) ("[T]here can be no absolute rule as to when it is proper for the district court to exclude from consideration an affidavit which contradicts earlier deposition testimony."); Guarantee Ins. Agency Co. v. Mid-Continental Realty Corp., 57 F.R.D. 555, 563 (N.D. Ill. 1972) ("Defendants [suggest] ... that the deposition is the more credible statement [when compared to the offsetting affidavit]. The Court refuses to make such a determination ....").

62. See, e.g., Inman v. Club on Sailboat Key, Inc., 342 So. 2d 1069, 1070 (Fla. Dist. Ct. App. 1977) ("A party who opposes summary judgment will not be permitted to alter the position of his or her previous... testimony in order to defeat summary judgment."); Fountaine v. Hadlock, 270 N.E.2d 222, 225 (Ill. App. Ct. 1971) (“[A] counter-affidavit does not place in issue material facts which had previously been removed from contention by a party's deliberate and unequivocal admissions under oath."); ITT Commercial Fin. Corp. v. Mid-America Marine Supply, 854 S.W.2d 371, 388 (Mo. 1993) (“[A] party may not avoid summary judgment by giving inconsistent testimony and then offering the inconsistencies into the record in order to demonstrate a genuine issue of material fact.”); Price v. Becker, 812 S.W.2d 597, 598 (Tenn. Ct. App. 1991) ("Two sworn inconsistent statements by a party are of no probative value in establishing a disputed issue of material fact."). 
without explanation, that party's prior testimony under oath would destroy summary judgment as we know it." ${ }^{63}$ Several of these courts have relied upon the Perma Research precedent to reach their conclusions, ${ }^{64}$ usually holding that offsetting affidavits should be disregarded absent a compelling justification for the contradiction. ${ }^{65}$

Yet Perma Research has proven controversial in several state jurisdictions. ${ }^{66}$ The Utah Supreme Court concluded, for example, that the decision's proclamations must be "administered with care," since "[i]t is common knowledge that witnesses sometimes misstate themselves, may not properly understand the question propounded, or give equivocal answers. ${ }^{\circ 7}$ An Ohio appellate court classified the Perma Research holding as the exception, not the general rule, to summary judgment procedures:

63. Buckeye Fed. Sav. \& Loan Ass'n v. Cole, No. CA 86-01-006, 1986 WL 13274, at *2 (Ohio Ct. App. Nov. 24, 1986).

64. See, e.g., Caplener v. Bluebonnet Milling Co., 911 S.W.2d 586, 590 (Ark. 1995) (ruling that the affidavit of the plaintiff's expert witness directly contradicted the expert's earlier deposition testimony and could not be used to establish a question of fact); Mays v. Ciba-Geigy Corp., 661 P.2d 348, 354-55 (Kan. 1983) (holding that although the party who submitted a contradictory affidavit was not the nonmoving party, the contradicting affidavit could not defeat summary judgment because the party had become a voluntary party as an intervenor and had a financial interest in the outcome of the case); Wachovia Mortgage Co. v. Autry-Barker-Spurrier Real Estate, 249 S.E.2d 727, 732 (N.C. Ct. App. 1978) (concluding that contradictory affidavits may not be used to defeat summary judgment where the only issue of fact created is the affiant's credibility).

65. See, e.g., Robinson v. Hank Roberts, Inc., 514 So. 2d 958, 961 (Ala. 1987) (holding that when a deposed party gives clear answers to unambiguous questions that negate the existence of a genuine issue of material fact, that party cannot, without explanation, later create such an issue with an affidavit that contradicts previous clear testimony); Wright v. Hills, 780 P.2d 416, 421 (Ariz. Ct. App. 1989) (stating that an inconsistent affidavit may preclude summary judgment if the affiant was confused at the deposition and the affiant explains those aspects of deposition testimony about which he or she was confused, or if the affiant lacked access to material facts and sets forth newly discovered evidence); Gaboury v. Ireland Road Grace Brethren, Inc., 446 N.E.2d 1310, 1314 (Ind. 1983) (holding that contradictory testimony in the affidavit of a nonmovant may not defeat a summary judgment motion where the only issue of fact raised is the credibility of the affiant).

66. For example, a Wisconsin court declined to adopt a rule similar to that of Perma Research and remarked that it was limited to applying existing statutes and rules of law:

While this issue is unresolved in this jurisdiction, the federal courts have established a rule to address such [offsetting] affidavits .... [The defendant] notes that this issue arises with some degree of frequency and urges this court to adopt a similar rule in Wisconsin. Without comment as to the desirability of such a rule, we must decline to do so.... Any changes in state summary judgment methodology must either come from the legislature or supreme court, and not this court.

Wolski v. Wilson, 497 N.W.2d 794, 797 (Wis. Ct. App. 1993).

67. Webster v. Sill, 675 P.2d 1170, 1173 (Utah 1983). 
While the rule of Perma Research is useful under the proper circumstances, it is an exception to the general rules concerning summary judgment, and should be used sparingly.... In considering the record, the court is not free to weigh the evidence in order to resolve factual disputes.... [W] here the affidavit is not by its nature too incredible to be believed by reasonable minds it must be considered by the court if it conflicts with an earlier deposition. ${ }^{68}$

This skepticism has led some state courts to grant or affirm summary judgment motions based on offsetting affidavits only reluctantly. ${ }^{69}$ Moreover, unlike federal courts, state courts do not unanimously condemn seemingly fraudulent affidavits. One Massachusetts appellate court held that a party is not bound by prior deposition testimony substantiating the opponent's version of the facts, allowing affiants the ability to contradict prior deposition testimony without hesitation. ${ }^{70}$ Several state courts have determined that a party responding to a summary judgment motion is entitled to have its offsetting affidavits considered by the trial judge. ${ }^{71}$ Other state courts have endorsed a limited definition of "contradiction" in this context, declaring that an affidavit that a federal court might label as "offsetting" still presents a fact issue worthy of jury resolution. ${ }^{72}$ The Massachusetts Supreme Judicial Court explained:

68. Mitchell v. TransOhio Sav., No. 10839, 1983 WL 3967, at*2 (Ohio Ct. App. Feb. 9, 1983).

69. See, e.g., Gamet v. Jenks, 197 N.W.2d 160, 164 (Mich. 1972) ("Had [the] plaintiff offered any reason for the contradiction [between the offsetting affidavit and his prior deposition testimony] we would be constrained to reverse [the grant of summary judgment]."); Henderson-Rubio v. May Dep't Stores, 632 P.2d 1289, 1295 n.6 (Or. Ct. App. 1981) ("Our decision is limited to... [cases] where the two statements are clearly inconsistent and no attempt is made to explain the inconsistency [between an offsetting affidavit and a prior deposition].”).

70. See Junkins v. Slender Woman, Inc., 386 N.E.2d 789, 790 (Mass. App. Ct. 1979) ("[I]t is sufficient that the plaintiff's later affidavit, if believed, indicated that the contrary is true. The conflict presents a question of credibility, which is not to be resolved by the judge on a motion for summary judgment." (citations omitted)).

71. See, e.g., Stefan v. White, 257 N.W.2d 206, 208-09 (Mich. Ct. App. 1977) (holding that a trial court must consider a plaintiff's affidavit filed in answer to a summary judgment motion); Delzer v. United Bank, 484 N.W.2d 502, 508 (N.D. 1992) (concluding that the trial court must consider the pleadings, admissions, affidavits, depositions, and interrogatories as well as all possible inferences therefrom in the light most favorable to the party opposing a summary judgment motion).

72. See, e.g., Anthony's Pier Four, Inc. v. Crandall Dry Dock Eng'rs, Inc., 489 N.E.2d 172, 178 (Mass. 1986) (ruling that had affidavits contradicted prior testimony, the factfinder would have needed to determine their credibility); Dryvit Sys., Inc. v. Feldspar Corp., No. C.A. 93-108, 1995 WL 941376, at *1-5 (R.I. Jan. 19, 1995) (concluding that even under the more stringent 
Although we recognize that there may be instances in which an affidavit denying deposition testimony may not fairly raise a genuine issue of material fact, we are reluctant to hold the plaintiff to conclusions of law stated in her deposition.... Although ... we are skeptical of the merits of the plaintiff's claim, particularly in light of the admissions in her deposition ... there was a genuine issue of material fact to be tried ....

Although the sham affidavit doctrine is generally associated with civil litigation, it has also arisen in certain criminal cases. Mississippi appellate courts have contemplated the doctrine's ramifications when considering the denial of petitioners' requests for post-conviction evidentiary hearings. In such cases, these courts have vigorously enforced the sham affidavit doctrine. ${ }^{74}$ The Mississippi Supreme Court declared in 1994:

There should be a strong presumption of validity of anyone's statement under oath. However, we are now faced with one statement or the other not being the truth.... "Where the petitioner's version is belied by previous sworn testimony, for example, as to render his affidavit a sham we will allow summary judgment to stand." If ever there was a sham, it is clearly within these allegations ....

While Mississippi courts have generally not allowed prisoners to explain why their offsetting affidavits conflict with prior representations, in other contexts and in other jurisdictions, state courts have proven more receptive to offsetting affidavits than federal courts. Affiants, therefore, more easily raise genuine issues of material fact in certain state courts. The diversity in state court approaches to offsetting affidavits greatly contrasts with the general acceptance of the Perma Research decision among federal courts.

standard, the affidavits in the instant case would not be disregarded because none of the statements flatly contradicted earlier deposition testimony).

73. Guenard v. Burke, 443 N.E.2d 892, 898 (Mass. 1982) (citations omitted); see also Halbert v. Lange, 233 S.W.2d 278, 280 (Ky. Ct. App. 1950) ("[A]dmissions will be conclusive only as long as they are allowed to stand. This conclusiveness, however, is destroyed if and when the party corrects his statements, explains them, or introduces other testimony showing that he could have been mistaken as to the facts.").

74. See, e.g., Kirksey v. State, 728 So. 2d 565, 567 (Miss. 1999) ("It is clear from [the plaintiff's] testimony that the affidavits to the petition are merely a sham."); Simpson v. State, 678 So. 2d 712, 716 (Miss. 1996) ("Simpson's claims are so totally contradicted by the record on its face so as to render his current affidavit a 'sham."').

75. Mowdy v. State, 638 So. 2d 738, 743 (Miss. 1994) (misquoting Harris v. State, 578 So. 2d 617, 620 (Miss. 1991)). 


\section{JUSTIFYING THE SHAM AFFIDAVIT DOCTRINE}

Although the sham affidavit doctrine has not received much attention from scholarly sources, federal and state courts have routinely applied it since 1969 . The rules of civil procedure in the federal and state systems do not speak to the issue of sham affidavits, but many judges who have faced the question have determined that offsetting affidavits do not create genuine issues of fact. Since courts can dispose of cases not presenting genuine issues, the sham affidavit doctrine, when enforced correctly, is consistent with the rules governing summary judgment. Supreme Court dicta and the capacity of lower courts to distinguish sham affidavits from affidavits that raise genuine issues justify the continuance of a flexible form of the doctrine.

\section{A. The Supreme Court's Implicit Support for the Sham Affidavit Doctrine}

Although the Supreme Court has not directly addressed the propriety of the sham affidavit doctrine, language from Justice White's majority opinion in Anderson v. Liberty Lobby ${ }^{76}$ suggests that the doctrine is consistent with the Court's modern approach toward summary judgment. In Anderson, the Court clarified that if a judge decides that based upon the evidence presented with the motion, a reasonable jury could not find for the nonmovant, summary judgment is proper. $^{77}$ This rule allows for the existence of the sham affidavit doctrine. If an affiant contradicts previous deposition testimony without explanation, the trial judge can rightly hold that a judgment in his favor would not be reasonable. As Justice White concluded: "The mere existence of a scintilla of evidence in support of the plaintiff's position will be insufficient; there must be evidence on which the jury could reasonably find for the plaintiff." 78

The Anderson Court reiterated that the dispositive issue in ruling on summary judgment motions is the determination of whether a genuine issue of material fact exists:

Only disputes over facts that might affect the outcome of the suit under the governing law will properly preclude the entry of summary judgment. Factual disputes that are irrelevant or

\footnotetext{
76. 477 U.S. 242 (1986).

77. See id. at 251.

78. Id. at 252.
} 
unnecessary will not be counted.... There is no requirement that the trial judge make findings of fact. The inquiry performed is the threshold inquiry of determining whether there is the need for a trial-whether, in other words, there are any genuine factual issues that properly can be resolved only by a finder of fact because they may reasonably be resolved in favor of either party. ${ }^{79}$

This holding coincides with the textual instruction that judges should construe and administer the Federal Rules to "secure the just, speedy, and inexpensive determination of every action." ${ }^{\circ 0}$ The Anderson Court distinguished a judge's determination regarding the existence of a genuine issue of material fact from a judge's determination on an issue of credibility. "[I]t is clear enough from our recent cases," Justice White wrote, "that at the summary judgment stage the judge's function is not himself to weigh the evidence and determine the truth of the matter but to determine whether there is a genuine issue for trial." ${ }^{\prime 1}$

It is the latter determination that allows judges to disregard sham affidavits. Trial courts can conclude that a particular factual dispute is irrelevant to a summary judgment motion if the dispute emanates from an affiant's inability to maintain a consistent story. Such a dispute would not "properly preclude the entry of summary judgment." ${ }^{, 2}$ By allowing a fabricated issue of fact to reach a jury, a judge would violate the responsibility to secure a "just, speedy, and

79. Id. at 248-50. The defendants moved for summary judgment after discovery, asserting that the plaintiffs had not met their burden of getting a libel claim to the jury, given the "actual malice" standards for libel established in New York Times v. Sullivan, 376 U.S. 254, 279-80 (1964).

80. FED. R. CIV. P. 1. Commentators generally agree that the Supreme Court's decisions in the 1985 Term revamped summary judgment practice in the federal courts. See, e.g., Jeffrey W. Stempel, A Distorted Mirror: The Supreme Court's Shimmering View of Summary Judgment, Directed Verdict, and the Adjudication Process, 49 OHIO ST. L.J. 95, 99 (1988) (noting that in three cases, the Supreme Court "specifically equated the standard for granting summary judgment... with the directed verdict standard of Federal Rule of Civil Procedure 50(a)," confirming previous practice). Similarly, Judge Patricia M. Wald of the District of Columbia Circuit reports the consensus that the Supreme Court has put summary judgment to greater use:

What almost everyone in the academic and legal communities agreed on was that the Supreme Court had moved summary judgment out of left field and onto first base, where it began shortening the innings by taking out runners before they could even begin to make the rounds. From 1986 to the present day, summary judgment has remained at first base and, some would say, it is getting progressively better at tagging runners out.

Wald, supra note 20, at 1914-15.

81. Anderson, 477 U.S. at 249.

82. Id. at 248 . 
inexpensive determination," ${ }^{83}$ because such a ruling would have the primary effect of preserving a claim that a reasonable jury could not believe.

Nor does the sham affidavit doctrine, when properly applied, infringe on the jury's prerogative to determine issues of credibility. In deciding motions for summary judgment, judges consider whether a reasonable jury could enter a judgment for the nonmovant. ${ }^{84}$ If, however, a nonmovant's affidavit appears a mere sham when compared with previous deposition admissions, the judge can rightly determine that a reasonable jury would accord the affidavit no evidentiary weight whatsoever. ${ }^{85}$ Although critics of the doctrine argue that Anderson stands for the proposition that judges in jury cases may not determine the credibility of evidence, ${ }^{86}$ a principle endorsed by the Court since long before the adoption of the summary judgment rule, ${ }^{87}$ Anderson specifically allows judges to grant summary judgment on disputed records. ${ }^{88}$ Therefore, if a court believes an offsetting affidavit was offered specifically to defeat a motion for summary judgment and that no jury could "properly proceed to find a verdict" for the affiant, ${ }^{89}$ summary judgment is proper. Consequently, while the Supreme Court has not definitively endorsed the sham affidavit doctrine, the Anderson decision implicitly supports it.

83. FED. R. CIV. P. 1.

84. See Anderson, 477 U.S. at 248.

85. See id. at 252.

86. See, e.g., Duane, supra note 24, at 1600-01 ("[The Supreme Court] has recently and unambiguously indicated (albeit in dictum) that summary judgment does not permit a judge to decide whether the affidavit of a witness may be rejected on the grounds that it conflicts with his earlier sworn testimony."); Holley, supra note 24, at 875 ("The ambiguity in Anderson is that, on the one hand, it generally tells the district judge to determine if the nonmovant's evidence is probative enough to go to trial while, on the other hand, it specifically tells the judge not to determine if that same evidence is credible.").

87. Indeed, the Supreme Court has noted that juries are well-equipped to determine the weight and credibility of witness testimony:

There are many things sometimes in the conduct of a witness upon the stand, and sometimes in the mode in which his answers are drawn from him through the questioning of counsel, by which a jury are to be guided in determining the weight and credibility of his testimony. That part of every case, such as the one at bar, belongs to the jury, who are presumed to be fitted for it by their natural intelligence and their practical knowledge of men and the ways of men; and so long as we have jury trials they should not be disturbed in their possession of it, except in a case of manifest and extreme abuse of their function.

Aetna Life Ins. Co. v. Ward, 140 U.S. 76, 88 (1891).

88. See Anderson, 477 U.S. at 249.

89. Id. at 251. 


\section{B. The Capability of Federal and State Courts to Distinguish Between Issues Requiring Jury Resolution and Sham Issues}

With no directly applicable holding from the Supreme Court on the sham affidavit doctrine, many federal and state courts have developed a distinction in the summary judgment context between credibility issues and sham issues. These courts have concluded that sham affidavits do not introduce issues of credibility, because they are precluded from consideration by the affiant's unambiguous deposition admissions..$^{90}$ This distinction is consistent with the basic justification of summary judgment-"enabl[ing] the court to expeditiously dispose of cases by giving judgment on the law where the material facts are not in dispute." ${ }^{, 91}$ In some circumstances, when parties admit in a deposition to certain conduct, they place the material facts of a case out of dispute, and a transparent subsequent denial of such admissions should not be considered. Indeed, the ability to dispose of sham claims is crucial, since the longer the case remains viable, the better a litigant's opportunities for settlement, regardless of that litigant's chances at trial. If courts could not enforce the sham affidavit doctrine, parties responding to summary judgment motions would have an incentive to submit fraudulent affidavits, hoping merely to preserve their claims long enough to reach a jury or inflate the value of their claims. ${ }^{92}$

90. See, e.g., Babrocky v. Jewel Food Co., 773 F.2d 857, 861 (7th Cir. 1985) ("Plaintiffs confuse credibility issues with the district court's duty to ignore sham issues in determining the appropriateness of summary judgment.... Otherwise, the very purpose of the summary judgment motion - to weed out unfounded claims, specious denials, and sham defenses-would be severely undercut."); Selsor v. Callaghan \& Co., 609 F. Supp. 1003, 1010 (N.D. Ill. 1985) ("Although our duty in ruling on this summary judgment motion is to resolve issues of credibility in [the plaintiff's] favor, this duty extends only to plausible issues of credibility.").

91. Surkin v. Charteris, 197 F.2d 77, 79 (5th Cir. 1952); see also David A. Sonenshein, State of Mind and Credibility in the Summary Judgment Context: A Better Approach, 78 Nw. U. L. REV. 774, 774 (1983) ("When properly employed, this [summary judgment] motion operates to conserve the resources of the courts by eliminating trials that would serve no purpose because no genuine issue of material fact remains to be resolved."); 10A CHARLES ALAN WRIGHT ET AL., Federal Practice AND Procedure § 2712, at 198 (Civil 3d ed. 1998) ("[In summary judgment proceedings,] dilatory tactics resulting from the assertion of unfounded claims or the interposition of specious denials or sham defenses can be defeated, parties may be accorded expeditious justice, and some of the pressure on court dockets may be alleviated.").

92. See Holley, supra note 24, at 878 ("Even if a jury would certainly find the plaintiff's second testimony to be incredible at trial, the plaintiff, by surviving summary judgment, will at least preserve the settlement value of the case and probably can proceed to settle for a minimal, yet completely undeserved, sum."). 
Some offsetting affidavits, however, are not fraudulent at all. Therefore, many federal courts have developed the general approach of presuming an offsetting affidavit is valid until proven a sham, thus allowing litigants responding to summary judgment motions more flexibility. ${ }^{93}$ Such a presumption coincides with the Supreme Court's admonition that "the inferences to be drawn from the underlying facts... must be viewed in the light most favorable to the party opposing the motion [for summary judgment]. ${ }^{, 4}$ The opportunity to explain contradictions between offsetting affidavits and prior deposition testimony is crucial, because an adverse ruling on a summary judgment motion terminates the nonmovant's claims. The Eleventh Circuit explained:

A definite distinction must be made between discrepancies which create transparent shams and discrepancies which create an issue of credibility .... To allow every failure of memory or variation in a witness's testimony to be disregarded as a sham would require far too much from lay witnesses and would deprive the trier of fact of the traditional opportunity to determine which point in time and with which words the witness (in this case, the affiant) was stating the truth. ${ }^{95}$

Many federal courts have proven their capacity to undertake extensive analyses in determining whether an offsetting affidavit, though initially presumed to be valid, is actually a sham. ${ }^{96}$ In these circumstances, judges often conclude, after scrutinizing an offsetting affidavit carefully, that it does not present a genuine issue of material

93. See, e.g., Darnell v. Target Stores, 16 F.3d 174, 179 (7th Cir. 1994) (“[E]ssential elements of [the plaintiff's] case were shown by his deposition testimony to be without factual foundation. His subsequent remedial effort consisted of filing ... contradictory affidavits. This effort was unavailing."); Durtsche v. American Colloid Co., 958 F.2d 1007, 1010 n.2 (10th Cir. 1992) (declaring that "an affidavit submitted on a summary judgment motion which conflicts with the affiant's earlier sworn testimony is not automatically disregarded"); Kennedy v. Allied Mut. Ins. Co., 952 F.2d 262, 267 (9th Cir. 1991) (remanding a case for a determination of whether an offsetting affidavit, presumed by the trial judge to be a "sham," created a genuine issue of material fact).

94. Matsushita Elec. Indus. Co. v. Zenith Radio Corp., 475 U.S. 574, 587 (1986).

95. Tippens v. Celotex Corp., 805 F.2d 949, 953-54 (11th Cir. 1986).

96. See, e.g., Lowie v. Raymark Indus., 676 F. Supp. 1214, 1217 (S.D. Ga. 1987) ("The benefit given to a nonmovant in summary judgment, generally, is also given to the narrower issue of determining whether the affidavit, in fact, contradicts prior testimony."); Office Supply Co. v. Basic/Four Corp., 538 F. Supp. 776, 785 (E.D. Wis. 1982) (“An affidavit of a witness which conflicts with his deposition testimony should . . . be considered on a summary judgment motion ...."). 
fact. $^{97}$ When courts evaluate offsetting affidavits in the light most favorable to the nonmovant, however, these affidavits sometimes appear consistent with previous deposition testimony, at least in part. ${ }^{98}$ Even within a single affidavit, some claims may raise genuine issues, while some claims may be shams. ${ }^{99}$

Similar to most federal courts, many state courts undertake lengthy reviews of deposition responses to compare them with those in offsetting affidavits. ${ }^{100}$ In striking contrast to federal courts, however, Tennessee courts have held that even if an offsetting affidavit clearly contradicts prior deposition testimony, a genuine issue of fact precludes summary judgment. These courts have sometimes refused to engage in a line-by-line analysis of the differing statements, citing the proposition that trial judges may not weigh evidentiary issues in summary judgment motions. ${ }^{101}$

97. See, e.g., Franks v. Nimmo, 796 F.2d 1230, 1237 (10th Cir. 1986) (“[The plaintiff's] earlier testimony is unequivocal. ... [T] his is one of those unusual cases in which the conflict... raises only a sham issue."); Barwick v. Celotex Corp., 736 F.2d 946, 960 (4th Cir. 1984) ("The entire content of the [offsetting] affidavit is conclusory, it does not set forth facts of which the plaintiff has personal knowledge and it does not give specific facts.... [The plaintiff's offsetting] affidavit is a vain effort to create an issue of fact...."); Dotson v. United States Postal Serv., 794 F. Supp. 654, 660 (E.D. Mich. 1991) ("Plaintiff, therefore, has mislead [sic] the court ... with two conflicting statements, each made under oath.").

98. See, e.g., Dibidale of La., Inc. v. American Bank \& Trust Co., 916 F.2d 300, 307 (5th Cir. 1990) ("To the extent they exist, discrepancies in those averments present credibility issues properly put to the trier of fact."); Holland v. Jefferson Nat'l Life Ins. Co., 883 F.2d 1307, 1314 n.3 (7th Cir. 1989) ("[The plaintiff's] affidavit presents no direct contradiction of any plain or unequivocal admission in her deposition. ... In her affidavit, [the plaintiff] merely clarified the sequence of events...."). In one case, the Eleventh Circuit found that, although a particular discrepancy in the plaintiff's testimony could affect the jury's determination of his credibility and persuasiveness, the discrepancy was not so inconsistent so as to warrant summary judgment:

Although a jury may find this discrepancy in [the plaintiff's] testimony to affect his credibility or to diminish its persuasiveness, it is not so inherently inconsistent that the court must disregard the previous affidavit .... Because assessing the credibility and weight of the evidence are questions of fact for the trier of fact ... summary judgment was improper.

Tippens v. Celotex Corp., 805 F.2d 949, 954-55 (11th Cir. 1986).

99. See, e.g., Lambert v. Independent Life \& Accident Ins. Co., 994 F. Supp. 1385, 1389-91 (M.D. Ala. 1998) (refusing to find the affidavit "inherently inconsistent" with prior testimony, although the court was "suspicio[us]" of some allegations).

100. See, e.g., Keeven v. Estate of Keeven, 882 P.2d 457, 465 (Idaho Ct. App. 1994) ("[The plaintiff's] deposition responses... are vague and evasive, but because they are vague and express uncertainty, they are not directly contradicted by statements in his later affidavit."); Borus v. Yellow Cab Co., 367 N.E.2d 277, 283 (Ill. App. Ct. 1977) ("[W]e have carefully examined both the deposition and the affidavit and have been able to find no real contradiction.").

101. See, e.g., Austin Powder Co. v. Thompson, No. 03A01-9408-CH-00294, 1995 WL 33778, at $* 9$ (Tenn. Ct. App. Jan. 27, 1995) ("We express no opinion regarding [the defendant's] 
Whether in federal or state courts, the determination that an offsetting affidavit is a sham, despite its presumption of validity, is squarely within the judge's discretion at the summary judgment stage. In 1993, the Seventh Circuit provided a cogent explanation of the federal judge's power:

Federal Rule of Civil Procedure 56 empowers a court to make a threshold determination of whether a factual issue is "genuine." This power does not emanate from the court's role as a fact-finder, a role which lays dormant during the summary judgment process. Rather, this power emanates from a court's ability to make an initial assessment of any evidence. A district court exercises its prerogative to assess evidence at trial by determining whether any evidence is admissible. The court is not acting as a fact-finder when it makes such determinations. A district court also exercises its prerogative to assess evidence at the summary judgment stage by determining whether an alleged factual conflict is "genuine."

Additionally, judges already make several relatively uncontroversial decisions similar to determining that an offsetting affidavit does not create a genuine issue of fact, providing supplementary support for the doctrine. One leading treatise notes that courts often grant summary judgment on disputed records without weighing evidence:

[C]ourts have sometimes ruled that facts offered by the nonmovant [for summary judgment] are insufficient as a matter of law to warrant a jury determination of liability, even when the facts are uncontested by the movant and concededly provide at least some evidentiary support to the nonmovant. ${ }^{103}$

credibility or the conclusion to be reached after the trial court evaluates the testimony and other relevant evidence that may be offered at trial. This is not our role."); Wilkerson v. Standard Knitting Mills, Inc., No. 1261, 1989 WL 120298, at*2 (Tenn. Ct. App. Oct. 11, 1989) ("There is no need to detail here the conflicting testimony given in various discovery depositions and affidavits filed in the case ....").

102. Unterreiner v. Volkswagen of Am., Inc., 8 F.3d 1206, 1212 (7th Cir. 1993) (disregarding an offsetting affidavit determined to be a sham). In dissent, Judge Rovner argued that the plaintiff's central assertion in the affidavit did not contradict his previous deposition testimony but simply created a "disparity." Id. at 1215 (Rovner, J., dissenting). She declared: "We may think that [the plaintiff's] recollection is selective, unreliable, or even fabricated, and a jury might agree. But a jury would render such an assessment having looked [the plaintiff] and the other witnesses in the eye-something no judge or jury has had the opportunity to do here." $I d$. at 1217 (Rovner, J., dissenting).

103. 11 MOORE ET AL., supra note 26, § 56.11[5][a]. 
A trial judge could conclude that because the affiant had already admitted to certain conduct, precipitating the motion for summary judgment, a simple denial of that admission does not present "sufficient" evidence to reach a jury as a matter of law. Just as a judge can grant a motion for summary judgment if a party's responses to that motion are extremely "weak" or "irrelevant," 104 so can a judge grant summary judgment against a party submitting a sham affidavit. Offsetting affidavits often represent "weak" attempts to deny previous admissions, and such affidavits should not clear the sufficiency threshold for jury resolution.

Moreover, courts can grant summary judgment when the evidence overwhelmingly favors one side. For example, a court will grant summary judgement when a defendant admits to certain conduct, proving liability as a matter of law. ${ }^{105}$ Similarly, an offsetting affidavit should not preclude summary judgment where the great weight of the evidence demonstrates the fallacies of that affidavit. Judges cannot decide issues of credibility, but judges have great discretion when credibility is not at issue. As an illustration, consider a circumstance in which two or more witnesses dispute the facts of a claim. The court cannot decide which person is telling the truth, as that is a matter of credibility. ${ }^{106}$ When a person submits a sham affidavit, however, there is no such dispute between two persons. Without impermissibly deciding a matter of credibility, judges can conclude that, in light of the affiant's prior deposition testimony, an offsetting affidavit is completely beyond belief.

104. See, e.g., Applegate v. Top Assocs., Inc., 425 F.2d 92, 96 (2d Cir. 1970) (requiring the plaintiff to "support vague accusation and surmise with concrete particulars"); Nieman v. Long, 31 F. Supp. 30, 30-31 (E.D. Pa. 1939) (disallowing a response that the defendant was "unable to ascertain whether the facts stated are true"); Gross v. Federal Reserve Bank, 29 F. Supp. 1005, 1005 (S.D. Ohio 1939) (rejecting the plaintiff's claim as "untenable, if not reprehensible").

105. See, e.g., United States v. 2204 Barbara Lane, 960 F.2d 126, 129 (11th Cir. 1992) (affirming the conviction of a defendant who did not respond to allegations of facilitating illegal drug transactions); United States v. Kasuboski, 834 F.2d 1345, 1350 (7th Cir. 1987) (holding that default admissions suffice for summary judgment purposes); Donovan v. Carls Drug Co., 703 F.2d 650, 651 (2d Cir. 1983) (affirming a judgment based on default admissions).

106. The Seventh Circuit recently noted this limitation on the court's ability to evaluate conflicting testimony:

Were the conflict at issue between statements given by two separate individuals, summary judgment would be inappropriate because the district court may not weigh conflicting evidence. The situation is quite different, however, when a witness has contradicted directly his or her own earlier statements without explaining adequately the contradiction or without attempting to resolve the disparity.

Bank of Ill. v. Allied Signal Safety Restraint Sys., 75 F.3d 1162, 1168 (7th Cir. 1996) (citations omitted). 
The sham affidavit doctrine appears consistent with the inherent powers of trial judges, who can distinguish between offsetting affidavits that create issues of genuine fact and offsetting affidavits that raise only sham issues. Judges already make several comparable decisions in determining whether a genuine issue of material fact requires jury resolution. Taken together, the Supreme Court's implicit support for the sham affidavit doctrine and the capability of judges to determine whether an offsetting affidavit presents a genuine issue are compelling reasons for federal and state courts to retain a flexible form of the doctrine.

\section{DEFINING THE SCOPE OF THE SHAM AFFIDAVIT DOCTRINE}

\section{A. Establishing Exceptions}

Presuming that an offsetting affidavit is a sham can disadvantage respondents to summary judgment motions who have legitimate reasons for contradicting prior deposition testimony. The sham affidavit doctrine should not lock parties into deposition admissions with such inflexibility. One way to ensure that each offsetting affidavit receives proper consideration is to allow affiants the chance to explain why their affidavit contradicts their prior deposition answers. Without this opportunity, the sham affidavit doctrine violates the court's responsibility to afford respondents to summary judgment motions all reasonable inferences. ${ }^{107}$ One court has explained that a party who has "emphatically and wittingly [sworn] to a fact" bears a "heavy burden ... when it seeks to jettison its sworn statement.",108 That burden, however, should not result in the perfunctory disposal of genuine issues raised by offsetting affidavits.

When no mitigating factors explain contradictions between offsetting affidavits and prior deposition testimony, courts have granted or affirmed summary judgments without compunction. ${ }^{109}$

107. See supra note 94 and accompanying text.

108. Pyramid Sec. v. IB Resolution, Inc., 924 F.2d 1114, 1123 (D.C. Cir. 1991).

109. See, e.g., Sinskey v. Pharmacia Ophthalmics, Inc., 982 F.2d 494, 498 (Fed. Cir. 1992) (holding that a party seeking to create an issue of fact through a "later, inconsistent declaration" must "provide a satisfactory explanation for the discrepancy"); Miller v. A.H. Robins Co., 766 F.2d 1102, 1104-05 (7th Cir. 1985) (affirming summary judgment when the plaintiff verified the authenticity of his deposition testimony before rejecting it without explanation in an offsetting affidavit). In the absence of a satisfactory explanation for an attempt to retract a sworn statement, a court will hold a plaintiff to his prior assertions of fact. One district judge explained: 
Generally, offsetting affidavits are impermissible in federal courts unless they provide a satisfactory or plausible explanation for any discrepancies. ${ }^{110}$ When a litigant denied knowledge on a certain subject during a deposition, one court determined that the litigant's offsetting affidavit, in which he presented specific recollections on the "forgotten" subject, was too unlikely to be genuine. ${ }^{111}$

In some circumstances, though, a reasonable justification for the contradiction may exist. For example, requiring deponents to remember intricate details of events occurring several years earlier may, on occasion, represent an excessive burden. The Eleventh Circuit encountered such a situation in 1986, when the deposition in question, taken in 1981, concerned work sites, dates, and products encountered by the affiant in the $1960 \mathrm{~s} .{ }^{112}$ Rather than asking for perfect recollection, the court allowed an offsetting affidavit to contradict certain aspects of the deposition testimony. ${ }^{11}$

The Fifth Circuit provided the leading case for the proposition that the sham affidavit doctrine is acceptable only given certain qualifications. In Kennett-Murray Corp. v. Bone,${ }^{114}$ the court allowed the respondent to a summary judgment motion to submit an offsetting affidavit. The affidavit clarified his answers to deposition questions that had confused him. ${ }^{115}$ The court began by holding that

It is true that clear, intelligent, unequivocal statements of fact, unfavorable to his position taken in his pleading, made under oath during the taking of a deposition, by a party to an action in full possession of his mental faculties should be considered as conclusively established and binding upon him in the absence of an offer of any explanation or modification, or of a showing of mistake or improvidence, and that this consequence should be attributed to such statements for the purpose of ruling upon a motion for summary judgment.

Southern Rendering Co. v. Standard Rendering Co., 112 F. Supp. 103, 108 (E.D. Ark. 1953).

110. See, e.g., Russell v. Acme-Evans Co., 51 F.3d 64, 67-68 (7th Cir. 1995) (requiring evidentiary materials that were more than "pretextual"); Colantuoni v. Calcagni \& Sons, Inc., 44 F.3d 1, 4-5 (1st Cir. 1994) (citing WRIGHT ET AL., supra note 91, at 30-31) (disregarding an offsetting affidavit that provided no explanation for a contradiction with prior testimony).

111. See Unterreiner v. Volkswagen of Am., Inc., 8 F.3d 1206, 1210 (7th Cir. 1993).

112. See Lane v. Celotex Corp., 782 F.2d 1526, 1533 (11th Cir. 1986).

113. See id.

114. 622 F.2d 887 (5th Cir. 1980).

115. The case concerned a promissory note and an employment agreement. Bone, the manager of one of Kennett-Murray's stockyards, signed both documents in 1975. The latter document rendered Bone personally liable to Kennett-Murray for half the net losses his division of the company suffered. Bone had signed virtually identical documents in 1974, except that those documents did not contain the personal liability clauses. In the 1975 promissory note, Bone acknowledged his share of the stockyard's losses for the 1974 fiscal year. When Bone resigned in 1977, Kennett-Murray demanded that he reimburse the company for the losses his division suffered under his tenure. Bone refused, so Kennett-Murray sued, seeking enforcement 
offsetting affidavits must be considered in determining whether summary judgment is appropriate: “An opposing party's affidavit should be considered although it differs from or varies his evidence as given by deposition .... and the two in conjunction may disclose an issue of credibility." "116 It then distinguished the Perma Research decision, holding that Bone's clarification did not constitute a sham, and that his excuses for the contradiction were acceptable:

Bone's affidavit did not purport to raise a new matter, but rather to explain certain aspects of his deposition testimony. Bone stated that he was confused during the deposition and at one point thought that the questioning concerned the promissory note whereas in fact it related to the signing of the employment contract. Bone's assertion is at least plausible.... The affidavit is not inherently inconsistent with Bone's earlier testimony. ${ }^{117}$

The court subsequently afforded Bone the benefit of several debatable propositions, including that his deposition could not be "taken literally" to mean that Kennett-Murray representatives had never discussed his new employment agreement with him:

Certainly, one would expect two business associates meeting to sign important documents to exchange some words. Bone may simply have meant that [the representative] did not affirmatively state anything about the specific content of either document. Such a view would not necessarily foreclose the possibility that [the representative] made some general remark that the contract was like the earlier version. ${ }^{118}$

Reactions to Kennett-Murray by subsequent courts have been mixed. One federal court concluded that its holding is inapplicable to

\footnotetext{
of the two documents. Bone responded that no consideration existed, because a KennettMurray representative fraudulently induced him to sign the employment agreement. During his deposition, however, Bone said Kennett-Murray officials made no representations to him regarding either the promissory note or the employment contract. Kennett-Murray moved for summary judgment based on this testimony. Accompanying his answer to the motion, Bone submitted an affidavit that alleged a Kennett-Murray representative told him his new agreement was identical to his previous agreement. To justify this contradiction, Bone testified that he meant to say that the representative was silent regarding the promissory note, but that the representative had fraudulently misinformed him about the new employment agreement. Rejecting Bone's arguments, the district court granted summary judgment. The court of appeals reversed. See id. at $889-90$.

116. Id. at 893 (quoting 6 MOORE ET AL., supra note $26, \S 56.522$ ).

117. Id. at 894 .

118. Id.
} 
cases involving offsetting affidavits that are proven to be shams. ${ }^{119}$ Another federal court, however, cited Kennett-Murray for the proposition that offsetting affidavits should be considered in summary judgment motions when affiants can explain their "sudden change of heart" with a " "plausible explanation.",120 Kennett-Murray remains the leading case holding that a litigant's explanation for contradictions between an offsetting affidavit and previous deposition testimony can render the affidavit relevant to a summary judgment motion ruling.

Since 1980, two generally acceptable excuses for contradictions between offsetting affidavits and previous deposition testimony have emerged in federal and state courts. The first exception, at issue in Kennett-Murray, arises when the person submitting an offsetting affidavit states that she was confused during the deposition. This explanation is so well-established in case law that courts have affirmed its viability even when the nonmovant does not assert it. ${ }^{121}$ When there is some basis for the respondent's claim of confusion, courts have allowed offsetting affidavits to correct previous deposition admissions and create material issues of fact. ${ }^{122}$ Judges have appeared more willing to allow offsetting affidavits to clarify

119. See Van T. Junkins \& Assocs. v. U.S. Indus., 736 F.2d 656, 658 (11th Cir. 1984). The dissenting judge in Junkins sharply disagreed with this holding: "The majority's claim . . . reads Kennett-Murray much too narrowly. Although the Kennett-Murray Court expressly avoided outright rejection of the Perma Research and Radobenko holdings, it clearly launched this Court's precedent in a different direction." Id. at 659 (Johnson, J., dissenting).

120. Unterreiner v. Volkswagen of Am., Inc., 8 F.3d 1206, 1210 (7th Cir. 1993) (quoting Richardson v. Bonds, 860 F.2d 1427, 1433 (7th Cir. 1988)).

121. See, e.g., Dotson v. United States Postal Serv., 794 F. Supp. 654, 659 (E.D. Mich. 1991) ("[A]n inconsistent affidavit may preclude summary judgment if the affiant was confused during the deposition."); Letson v. Liberty Mut. Ins. Co., 523 F. Supp. 1221, 1230 (N.D. Ga. 1981) (“[I]f the deposition reflects confusion and the affidavit assertion is plausible, then the affidavit should not be rejected. These mitigating factors are not present in the case at bar."). In a recent medical insurance case, the Eighth Circuit allowed a physician's deposition testimony regarding the plaintiff's chances for recovery to be considered, though the physician had admittedly confused the nature of the plaintiff's occupation. See Herring v. Canada Life Assurance Co., 207 F.3d 1026, 1030-31 (8th Cir. 2000). The doctor's opinion regarding the plaintiff's ability to work, the court ruled, was "the same regardless of whether [the plaintiff] worked as a draftsman or a senior traffic manager." Id. at 1031.

122. See, e.g., RSBI Aerospace, Inc. v. Affiliated FM Ins. Co., 49 F.3d 399, 402 (8th Cir. 1995) (observing that the deposition in question reflected confusion, which the offsetting affidavit rightfully explained); Kim v. Ingersoll Rand Co., 921 F.2d 197, 199 (8th Cir. 1990) (finding the plaintiff's explanation of the discrepancy with prior testimony adequate where the plaintiff, who did not speak English, was relying on a translator throughout his deposition); Clapp v. Oregonian Publ'g Co., 732 P.2d 928, 931 (Or. Ct. App. 1987) (acknowledging that Oregon state courts allow for the confusion exception). 
contradictions when confusion resulted from a case's highly technical subject matter. For example, when a plaintiff's medical expert did not distinguish in his deposition between different standards of care for particular surgeons, the expert, who was confused by the deposition questions, was allowed to modify his testimony with an offsetting affidavit. ${ }^{123}$ In a different case, the Seventh Circuit allowed a plaintiff in a products liability action to submit an offsetting affidavit that contradicted a damaging deposition admission concerning her failure to search for the defendant's safety device. ${ }^{124}$ The appellate court held that the plaintiff's affidavit, though submitted after the trial judge had granted summary judgment for the defendant, should nevertheless have been considered, since it clarified confusing testimony in a complex case. ${ }^{125}$

Yet the simple assertion that an offsetting affidavit is entitled to consideration in a summary judgment motion because of confusion during a deposition is not always sufficient. When parties testify clearly during depositions, displaying no confusion whatsoever, some federal courts have not allowed those parties to contradict their testimony with offsetting affidavits. ${ }^{126}$ One Ohio federal court even rejected a party's attempt to introduce evidence regarding certain medications he had taken shortly before his deposition. ${ }^{127}$ Those medications had allegedly induced the affiant's confusion. ${ }^{128}$

The second generally accepted justification for contradictions between offsetting affidavits and prior deposition testimony arises when the affiant obtains new evidence not available during the deposition. This exception is generally uncontroversial, and it has been recognized by numerous federal and state courts. ${ }^{129}$ One federal

123. See Ramos v. Geddes, 137 F.R.D. 11, 11-12 (S.D. Tex. 1991).

124. See Deimer v. Cincinnati Sub-Zero Prod., Inc., 990 F.2d 342, 345-46 (7th Cir. 1993). Deimer, a nurse, was injured when she moved one of the defendant's products across a hospital room. See id. at 344. She admitted in her deposition that she had not searched for the safety device, which would have prevented her injuries. See id. at 345.

125. See id. at $345-46 \&$ n.3.

126. See, e.g., EEOC v. Oak Lawn Ltd. II, 987 F. Supp. 647, 651 n.2 (N.D. Ill. 1997) ("The deposition does not indicate that [the defendant] was confused. [The defendant] answered numerous questions about [his company], illustrating that he understood the workings of [his company].").

127. See Mays v. Hunter, 717 F. Supp. 1247, 1251 (S.D. Ohio 1989).

128. See id. at 1250 (discounting the plaintiff's explanation that the "significant amounts of pain killers" he had ingested, coupled with "numerous surgeries, consultations and examinations," led him to confuse the accrual date of his cause of action during his deposition).

129. See, e.g., Adelman-Tremblay v. Jewel Cos., 859 F.2d 517, 521 (7th Cir. 1988) (rejecting affidavits unless there is new evidence and the new affidavit helps to give foundation to the 
court considered an offsetting affidavit when the affiant claimed that newly discovered photographs, unavailable during his deposition, had refreshed his memory of certain events. ${ }^{130}$ Another court allowed an expert witness to submit an offsetting affidavit when recently discovered evidence changed his opinion on the causation issues involved in the case. ${ }^{131}$ Many judges enforce this exception quite literally, however. If the affiant had access to the information during the previous deposition, it is generally not considered "new" for the purposes of submitting an offsetting affidavit. ${ }^{132}$

Courts have disagreed on how to treat situations in which respondents offer unique explanations for contradictions between offsetting affidavits and prior deposition testimony. Some federal courts consider all offsetting affidavits when their contradiction with prior testimony is reasonably justified. ${ }^{133}$ Other federal courts,

claim); Waitek v. Dalkon Shield Claimants Trust, 908 F. Supp. 672, 686 (N.D. Iowa 1995) (finding that a plausible change in testimony may still establish a genuine issue of material fact); Sisson v. Hatteras Yachts, Inc., No. 87C0652, 1989 WL 106584, at *2 (N.D. Ill. Sept. 14, 1989) (considering an offsetting affidavit where an expert witness changed his mind following the introduction of new evidence); O’Brien v. Analog Devices, Inc., 606 N.E.2d 937, 939 (Mass. App. Ct. 1993) (rejecting an offsetting affidavit because it lacked a foundation in new evidence). Idaho state courts have been particularly receptive to this justification, declaring at one juncture that there is "no 'contradiction' where the witness asserts in his affidavit facts which, at the time of his earlier deposition, he specifically had asserted he could not recall." Tolmie Farms, Inc. v. J.R. Simplot Co., 862 P.2d 299, 302 (Idaho 1992) (quoting Kennedy v. Allied Mut. Ins. Co., 952 F.2d 262, 266-67 (9th Cir. 1991)).

130. See Rowson v. Kawasaki Heavy Indus., 866 F. Supp. 1221, 1230-31 (N.D. Iowa 1994):

Such an explanation of [the plaintiff's] change in testimony is at least plausible, and the court should not now pass on what credibility a jury may give it or the changed testimony. Although [the defendant] asserts that [the plaintiff's] new testimony is inherently inconsistent with his prior testimony, and that there was no confusion about that testimony at the time of the deposition, the court is not persuaded that these factors are relevant to circumstances in which the reason presented for the change in testimony is refreshed recollection.

131. See Endo v. Albertine, 863 F. Supp. 708, 724 (N.D. Ill. 1994) (allowing an expert witness to respond to newly discovered reasoning and methodology of the opposing expert).

132. See, e.g., Bank of Ill. v. Allied Signal Safety Restraint Sys., 75 F.3d 1162, 1172 (7th Cir. 1996) (holding that a car seatbelt's propensity for inertial release was not newly discovered evidence, since the plaintiffs had access to that information before admitting their son's seatbelt had not been buckled); Vanlandingham v. Ford Motor Co., 99 F.R.D. 1, 3 (N.D. Ga. 1983) (refusing to apply the "new evidence" exception when a witness "was and has been available to counsel for all parties").

133. See, e.g., Dunavant v. Moore, 907 F.2d 77, 79 n.4 (8th Cir. 1990) (allowing an issue of material fact to proceed beyond summary judgment despite an obvious contradiction in testimony); Rowson, 866 F. Supp. at 1230 (permitting a plausible change in testimony at the summary judgment phase of a claim). 
however, have rejected alternative excuses for contradictions, ${ }^{134}$ with the Seventh Circuit declaring them "little more than bald assertions" without merit. ${ }^{135}$ Generally, state courts have refused to accept excuses a reasonable jury could not believe. ${ }^{136}$

The reasonableness test seems consistent with the judge's responsibility to determine what constitutes a genuine fact. While federal and state courts should continue to allow litigants to explain contradictions between offsetting affidavits and previous deposition testimony on the basis of confusion or new evidence, other equally legitimate justifications are conceivable. Courts should, therefore, use an affidavit-specific analysis and evaluate each excuse for contradiction on its own merits.

\section{B. Applying the Doctrine to Non-Parties}

Courts that implement the sham affidavit doctrine also must determine whether to extend its provisions to nonparties. Several federal courts have disregarded affidavits in those situations, especially when they do not explain contradictions with prior testimony. ${ }^{137}$ The Seventh Circuit provided a representative example, affirming a grant of summary judgment in a products liability action against a plaintiff who relied on the offsetting affidavit of an expert witness:

We can think of no reason, however, not to apply [the sham affidavit] rule to the present case involving the testimony and affidavit of the plaintiff's sole expert witness. The purpose of summary judgment motions-to weed out unfounded claims,

134. See, e.g., Colantuoni v. Calcagni \& Sons, Inc., 44 F.3d 1, 5 (1st Cir. 1994) (rejecting the plaintiff's excuse that while his deposition testimony described his state of mind at the time of the deposition, his affidavit described his state of mind at the time of the accident in question); Thurman v. Sears, Roebuck \& Co., 952 F.2d 128, 137 n.23 (5th Cir. 1992) (rejecting the plaintiff's excuse that he was "outwitted" by defense counsel during his deposition).

135. Babrocky v. Jewel Food Co., 773 F.2d 857, 861 (7th Cir. 1985).

136. See, e.g., Robinson v. Hank Roberts, Inc., 514 So. 2d 958, $961-62$ (Ala. 1987) (finding no genuine issue of material fact where the plaintiff could have known of relevant facts at the time of his deposition); Williams v. Logan County Coop. Power \& Light Ass'n, 594 N.E.2d 195, 197 (Ohio Com. Pl. 1991) (holding that "memory gap affidavits" do not create a genuine issue of material fact).

137. See, e.g., Rohrbough v. Wyeth Lab., 916 F.2d 970, 975 (4th Cir. 1990) (noting the contradictory affidavit's questionable timing in answering the motion for summary judgment); Martin v. City of New York, 627 F. Supp. 892, 896 (E.D.N.Y. 1985) (holding that summary judgment is not defeated by submission of an affidavit by plaintiff's mother contradicting both her own and the plaintiff's prior testimony). 
specious denials, and sham defenses-is served by a rule that prevents a party from creating issues of credibility by allowing one of its witnesses to contradict his own prior testimony. ${ }^{138}$

Other courts, however, have allowed offsetting affidavits from nonparties to be considered in summary judgment motions, even if they contradict prior deposition testimony. ${ }^{139}$ The Eleventh Circuit explained its reasoning for allowing such testimony:

Here there is little chance of sham factual issues. [The expert] is a disinterested witness and it is our view that any inconsistency in his testimony is more likely the result of his faulty memory than a predisposition to lie. Thus, while a district court may find that a party's contradictory affidavit constitutes a sham, we would be unable, absent great trepidation, to affirm a similar finding with respect to a disinterested witness' contradictory affidavit. ${ }^{140}$

The sham affidavit doctrine is based on functional concerns, and the same functional concerns can arise whether the contradicting witness is a party or a nonparty to a lawsuit. The conclusion reached by the Seventh Circuit, therefore, appears correct. When the nonparty is completely detached from the lawsuit, courts could rightly determine that an offsetting affidavit was not introduced simply to defeat the summary judgment motion and preserve the claim. Trial judges should consider each offsetting affidavit submitted by a nonparty separately, rather than adhering to a general rule that prohibits their consideration.

\section{BACKSTOPPING THE SHAM AFFIDAVIT DOCTRINE}

Most federal and state courts have adopted an approach toward offsetting affidavits that is consistent with the applicable rules of civil procedure. Nevertheless, certain reforms would assure that disposing of sham affidavits is proper in certain circumstances. Those reforms include modifying the Federal Rules of Civil Procedure to address

138. Adelman-Tremblay v. Jewel Cos., 859 F.2d 517, 521 (7th Cir. 1988) (quotations and citations omitted).

139. See, e.g., Gilbert v. Texas Mental Health \& Mental Retardation, 919 F. Supp. 1031, 1037 (E.D. Tex. 1996) (explaining that a court must consider all of the evidence before it in deciding a summary judgment motion); Kunzman v. Enron Corp., 902 F. Supp. 882, 896-98 (N.D. Iowa 1995) (allowing the introduction of an affidavit that contradicted previous deposition testimony from someone other than the affiant).

140. Lane v. Celotex Corp., 782 F.2d 1526, 1530-31 (11th Cir. 1986) (citations and emphasis omitted). 
problems raised by offsetting affidavits and increasing reliance on the sanctions authorized by Rule 11 to deter fraudulent representations. Implementing these suggestions would codify the approach already adopted by many federal and state courts and eliminate any remaining uncertainty regarding the justifications for the sham affidavit doctrine.

\section{A. Revising Rule 56}

A revision of Federal Rule of Civil Procedure 56 would provide federal judges still skeptical of the sham affidavit doctrine with a textual instruction to disregard certain offsetting affidavits. Such a revision would not be unprecedented. Since its adoption in 1937, Rule 56 has been amended three times-in 1946, 1963, and 1987. Two of these three amendments allowed for increased utilization of summary judgment. ${ }^{141}$ Revising Rule 56 to incorporate the sham affidavit doctrine would effect a similar improvement.

The current version of Rule 56 allows courts to sanction parties who present affidavits "in bad faith or solely for the purpose of delay." ${ }^{142}$ Rule 56(g) could be modified not only to allow for the possibility of judicial sanctions, but also to allow judges to ignore offsetting affidavits that raise only sham issues. ${ }^{143}$ While determining the exact language of the new textual provision might be problematic, this revision would conclude the debate over whether Supreme Court decisions like Anderson actually justify the sham affidavit doctrine. ${ }^{144}$ Moreover, since most states pattern their rules of civil procedure on the federal model, ${ }^{145}$ many would presumably follow the federal lead in recognizing the explicit problems posed by offsetting affidavits. A new version of Rule 56 would not lead to complete unanimity, but it would certainly assure federal courts already so inclined that disregarding sham affidavits is the correct disposition.

141. See FED. R. Civ. P. 56 advisory committee's notes.

142. FED. R. CIV. P. 56(g).

143. This revision would answer James Joseph Duane's concern regarding rule construction. Duane argues that since Rule 56(e)'s "fairly unambiguous language" contains no requirement that affidavits be consistent with all the witness's statements, that requirement should not be imputed into the other provisions of the rule. Duane, supra note 24, at 1601-02.

144. See supra notes 86-89 and accompanying text.

145. See 1 William W. Barron \& Hon. Alexander Holtzoff, Federal Practice AND PROCEDURE $\S \S 9.1-9.53$, at 46-80 (Charles Alan Wright ed., 1960). 


\section{B. Increasing Reliance on Rule 11}

In addition to, or instead of, revising Rule 56, federal courts could impose Rule 11 sanctions on parties and on attorneys who submit sham affidavits to the court. Federal Rule of Civil Procedure 11(b) provides that by presenting a "pleading, written motion, or other paper"-unquestionably including affidavits-to the court, the attorney essentially certifies that the document is submitted to the court for a proper purpose. ${ }^{146}$ Rule $11(\mathrm{c})$ then provides federal courts with the authority to sanction those who violate these provisions, even on the court's own initiative:

If, after notice and a reasonable opportunity to respond, the court determines that subdivision (b) has been violated, the court may, subject to the conditions stated below, impose an appropriate sanction upon the attorneys, law firms, or parties that have violated subdivision (b) or are responsible for the violation. ${ }^{147}$

Although sanctions under Rule 11 are "limited to what is sufficient to deter repetition of such conduct or comparable conduct by others similarly situated," ${ }^{148}$ attorneys who submit sham affidavits to cause unnecessary delay could face hefty fines. The deterrent effect on the submission of other sham affidavits would be uncertain, especially in state courts, but it is reasonable to suggest that the fear of significant financial penalty would discourage attorneys from advising their clients to contradict, without good reason, a deposition admission with an offsetting affidavit.

Few trial judges have assessed sanctions against litigants who manufacture issues of fact to avoid summary judgments, ${ }^{149}$ but courts

146. Specifically, the rule requires that:

(1) [the document] is not being presented for any improper purpose, such as to harass or to cause unnecessary delay or needless increase in the cost of litigation; (2) the claims, defenses, and other legal contentions therein are warranted by existing law or by a nonfrivolous argument for the extension, modification, or reversal of existing law or the establishment of new law;

(3) the allegations and other factual contentions have evidentiary support or, if specifically so identified, are likely to have evidentiary support after a reasonable opportunity for further investigation or discovery; and

(4) the denials of factual contentions are warranted on the evidence or, if specifically so identified, are reasonably based on a lack of information or belief.

FED. R. CIV. P. 11(b).

147. FED. R. CIV. P. 11(c)(2).

148. Id.

149. But see Margo v. Weiss, 213 F.3d 55, 65 (2d Cir. 2000): 
have recognized their powers under Rule 11 to do so. ${ }^{150}$ Attorneys, moreover, have been found liable under Rule 11 for submitting sworn statements that blatantly contradict the evidence already on file. In one federal case in Texas, the court assessed a $\$ 5,000$ fine against an attorney who submitted a disclaimer in which he stated that the plaintiff's minor children had no financial interest in the plaintiff's pending lawsuit. ${ }^{151}$ In a previous deposition, though, the plaintiff had acknowledged that her children stood to collect a large amount of money if she prevailed at trial. ${ }^{152}$ The court soon reached the "inescapable conclusion" that the attorney had attempted to create the appearance of diversity jurisdiction by refusing to name the nondiverse minors as plaintiffs and had concealed their identities from the court when he realized their presence as parties would defeat diversity jurisdiction. ${ }^{153}$ The federal judge refused to tolerate this conduct, holding: "The minimum standards of this noble profession were not maintained but were subverted for improper purpose. $" 154$

It was objectively unreasonable for plaintiffs' counsel to file affidavits, delayed deposition errata sheets and supplemental interrogatory answers in which the plaintiffs contradicted their earlier deposition testimony and interrogatory answers. As the district court observed, there was no basis whatsoever upon which plaintiffs' counsel could argue that this Court might read or change the Perma Research rule in a way that rendered it inapplicable to such tactics. The district court acted well within its discretion in granting the defendants reimbursement for a portion of their attorneys' fees to compensate them for the waste of the court's and counsel's time.

150. See, e.g., Richardson v. Bonds, 860 F.2d 1427, 1433-34 (7th Cir. 1988) (suggesting that the submission of sham affidavits in response to a summary judgment motion came "perilously close" to violating Rule 11); Selsor v. Callaghan \& Co., 609 F. Supp. 1003, 1010 n.8 (N.D. Ill. 1985) (finding a direct contradiction of previous deposition testimony could be grounds for Rule 11 sanctions); McCullough v. Spitzer Motor Ctr., Inc., No. 64465, 1994 WL 24281, at*7 (Ohio Ct. App. Jan. 27, 1994) (allowing the use of Rule 11 sanctions to deter the filing of a false affidavit).

151. See Hearld v. Barnes \& Spectrum Emergency Care, 107 F.R.D. 17, $19-20$ (E.D. Tex. 1985).

152. See id. at 18-19.

153. Id. at 19 .

154. Id. at 19-20. The federal judge hesitated to assess a penalty under Rule 11, as the opinion reflected:

The Court admits to a measure of reluctance in coming to grip with the questions raised by Plaintiffs' counsel's conduct. [Counsel] is well known to the Court. He has appeared in numerous matters at both trial and pre-trial levels and has, to date, comported himself with the highest standards of the legal profession from both a competency and ethical standpoint. Id. at 19 
Since "an affidavit is a sworn document, declared to be true under the penalties of perjury, ${ }^{, 155}$ persons submitting sham affidavits face possible criminal prosecution if they mislead the court. ${ }^{156}$ This threat, combined with an increased reliance on Rule 11, could eliminate many of the problems posed by sham affidavits in federal courts. While assessing sanctions would not do away with all sham affidavits, such sanctions would deter persons from attempting to maintain their claims through an improper procedural mechanism.

\section{CONCLUSION}

Though it has escaped attention from all but a few legal commentators, the sham affidavit doctrine has emerged as an important aspect of summary judgment practice, both in federal and state courts. Judges have generally handled the problems presented by offsetting affidavits equitably, evaluating each submission on its own merits. Instead of adopting an unyielding stance to offsetting affidavits, courts should allow persons to overcome the presumption against offsetting affidavits with reasonable explanations. If the affiant cannot explain discrepancies with previous deposition testimony on the basis of confusion, new evidence, or another legitimate excuse, only then should the court disregard the affidavit as a sham. Reaching such a determination coincides with judges' responsibility to allow only genuine issues of material fact to reach juries, as emphasized by the Supreme Court's decision in Anderson.

Modifying Rule 56 or imposing sanctions pursuant to Rule 11 would solve many of the problems posed by the sham affidavit doctrine, especially in federal courts. When correctly applied, the sham affidavit doctrine serves both policy and procedural ends, as the D.C. Circuit explained in 1991: "[T]he cases resting summary judgment on sworn but repudiated party assertions reflect both a judicial insistence that parties proceed with real care in their supporting affidavits or testimony and a belief that parties' opportunism should not readily imperil summary judgment." ${ }^{157}$

155. 11 MOORE ET AL., supra note 26, § 56-14[1][b]; see also Smith v. Ashley, 332 N.E.2d 32, 34 (Ill. App. Ct. 1975) (holding that by disregarding sham affidavits, the court enforced "a judicial policy, the purpose of which is to eliminate the temptation to commit perjury"); Meier v. Pocius, 150 N.E.2d 215, 216 (Ill. App. Ct. 1958) ("Plaintiff having sworn, deliberately and repeatedly ... should not now be invited to commit perjury and change his testimony upon the trial of the case or so reconstruct it as to avoid the consequence of his deposition.").

156. See FED. R. CIV. P. 56(g).

157. Pyramid Sec., Ltd. v. IB Resolution, Inc., 924 F.2d 1114, 1124 (D.C. Cir. 1991). 
[Vol. 50:261

Accepted by every federal circuit that has considered the issue and a large number of state courts, the sham affidavit doctrine preserves the central purpose of summary judgment while allowing respondents to such motions all reasonable inferences. The doctrine represents a reasoned approach to a complex problem of civil procedure. 